\title{
PERVERSE SUPPLY CURVES IN LESS DEVELOPED ECONOMIES?
}

\author{
J. H. L. JOOSTEN \\ Professor in Agricultural Economics of the Tropics, \\ Agricultural University, Wageningen, Holland
}

\begin{abstract}
SuMMARY
The theory that perverse supply curves for cash-crop commodities exist in subsistence economies is very firmly held by Prof. BoEke according to whom this theory is borne out in particular by the native rubber industry of Indonesia. An analysis of the relationship of rubber and rice prices to exports of native rubber in two main producing regions of Indonesia clearly shows that where the peasant rubber producer has alternative opportunities he reacts in an entirely "normal" manner to changes in the price of rubber relative to rice.
\end{abstract}

"It has often been categorically stated that the supply curve of produce of the small family farmer will be perverse. Between the wars, the existence of such a supply curve, at least for peasant farmers in Asia and Africa, was accepted dogma. It was based on the assumption that such farmers had a certain, rather low "target" of cash income and that, once this was attained, the farmer would only work as hard as was necessary to maintain it. If the price of his produce rose, he would produce less and enjoy more leisure; if it fell, he would produce more in an attempt to enjoy the same income as before. Studies that have been made to test this hypothesis, for commercial crops, have not, however, borne it out". AnNe Martin (1).

This subject has been studied in relation to rubber and cocoa farmers who have an alternative activity. The argument was not that perverse supply curves never exist in the case of individual agricultural products, but that their existence is due to the absence of alternative opportunities rather than on the farmer's prosperity or status.

Professor J. H. Boeke (2) was one of the exponents of the theory of the existence of perverse supply curves, these being essential to his conception of the pre-capitalistic economy of the East Asian village. He advocated this theory with great tenacity in a series of books and publications but never adduced sufficient material in support of his theories. In one of his latest books "The evolution of the Netherlands Indies Economy" (1947) he describes in the following terms the rubber restrictions, imposed by the Netherlands Indies Government.

"The system used for the third group (the peasant rubber-planters in the Outer-Provinces) was quite different. Here the principle of a special export tariff was -adapted as an emergency measure in 1934 ; by raising the tariff it was possible to lower the price level of native rubber, so that production in native areas would not exceed the proportionate volume of exports permitted by the restriction regulations. The Government expected that the amount of rubber, supplied by the native growers would be directly proportional to the price of rubber. This proved to be an error, since it left out of account the fact that the native producer often depends for his living on the sale of rubber. Such a man will

1) Received for publication January 20, 1960. 
intensify the tap and increase the supply every time the price he received per unit of rubber goes down. The supply by these producers, therefore, was inversely proportional to the price of rubber minus export duties".

Moreover it is often said that the peasant farmer of the less developed areas manages his farm inefficiently and irrationally. But a scrutiny of the facts shows that the peasant farms his land as rationally as possible under the social and economic conditions affecting him and within the limits of his opportunities as regards labour, land, markets, capital, knowledge and managerial skill.

An analysis of the relationship between prices of rubber and rice, and the exports of native rubber in two rubber producing regions (Palembang and Wester Afdeling van Borneo) clearly shows that where he has alternative opportunities the peasant rubber producer reacts in an entirely "normal" manner to changes in the price of rubber relative to rice. As the prices of household commodities are closely correlated with prices of rice, the "value" of rubber expressed in rice is chosen as the price index. Moreover rice production is one of the main alternatives to rubber production.

The cost of plantation maintenance, installation and equipment is very slight, so that except for a small outlay on implements (knife and pails) and alum, labour is the factor that determines the cost of rubber production. This means that labour has opportunities and is productive in alternative activities, in this instance mainly subsistence farming in which rubber production is actually only of subsidiary importance.

In this connection BAUER (3) points out that

"readiness and ability of producers in many under-developed countries to abandon or reduce subsistence production in favour of production for the market are well known; the willingness to do so indicates the desire to shift to more productive activities. This suggests that producers will tend to revert to subsistence production if net returns in the exchange sector decline relatively to those in the subsistence sector".

This statement is well demonstrated by the following figures (table 1) relating to native rubber exports, price of rubber and purchasing power of rubber collected for Palembang and Wester Afdeling van Borneo (Indonesia).

The figures show:

1. A close connection between the changes in prices of rubber and the rubber supply; in cases of perverse supply (increased supply and decrease of rubber price - see I and II - 1931 and II - 1935) the price of rice fell more rapidly than the price of rubber (shown by the minus sign in the relevant column).

2. Rubber supply and rice production are competitive percentage change in the rubber supply percentage change in the (relative) price of rice $=$ negative.

In some exceptional cases the changes in production or price were of minor importance.

3. Although restrictions were imposed in June 1934 by means of a special export tariff, there was no change in the relationship between supply and prices. 
Table 1 Quarterly changes in exports and prices of native rubber as percentages of the preceding quarter.

\begin{tabular}{|c|c|c|c|c|}
\hline & quarter & $\begin{array}{l}\text { Export } \\
\text { volume }\end{array}$ & $\begin{array}{l}\text { Rubber } \\
\text { price }\end{array}$ & $\frac{\text { Price of rubber per } \mathrm{kg}}{\text { Price of rice per } \mathrm{kg}} \times-1$ \\
\hline $\begin{array}{c}\text { I } \\
\text { II } \\
\text { III } \\
\text { IV } \\
\text { II } \\
\text { II } \\
\text { III } \\
\text { IV } \\
\text { I } \\
\text { II } \\
\text { III } \\
\text { IV } \\
\text { I } \\
\text { II } \\
\text { III } \\
\text { IV } \\
\text { I } \\
\text { II } \\
\text { III } \\
\text { IV } \\
\text { I } \\
\text { II } \\
\text { III } \\
\text { IV } \\
\text { I } \\
\text { II }\end{array}$ & $\begin{array}{l}-1934 \\
-1935 \\
-1936\end{array}$ & $\begin{array}{ll}-1 & \\
-1 & \\
-17 & \\
-31 & \\
& +61 \\
& +1 \\
-12 & \\
-6 & \\
-25 & \\
-54 & \\
& +51 \\
& +44 \\
-25 & \\
& +83 \\
& +35 \\
0 & +50 \\
& +26 \\
-40 & \\
-46 & \\
& +49 \\
-41 & +62 \\
-3 & \\
& +30 \\
& +1\end{array}$ & $\begin{array}{rr}-26 & \\
-11 & \\
-32 & \\
-15 & \\
-8 & \\
-17 & \\
-27 & \\
-14 & \\
-21 & \\
-27 & \\
& +36 \\
-13 & 0 \\
& +38 \\
& +33 \\
0 & +21 \\
& +28 \\
-37 & \\
-33 & \\
-10 & +5 \\
-18 & \\
-14 & \\
-9 & 0\end{array}$ & $\begin{array}{ll}+22 & \\
+5 & \\
+28 & \\
+12 & \\
& -9 \\
+26 & -18 \\
+18 & \\
+16 & \\
+10 & \\
+33 & -45 \\
+11 & \\
& -66 \\
+1 & -39 \\
& \\
+35 & -43 \\
+43 & \\
+1 & \\
+22 & -14 \\
+26 & \end{array}$ \\
\hline
\end{tabular}

Notes : a) The rubber prices given are the prices of standard sheets Batavia less special export duty.

b) In III - 1936 the devaluation of the guilder upset prices and from I - 1937 $\because$ onward the tariff system was changed to the individual licence system with negotiable rubber coupons.

Unfortunately no figures are available on the acreage of the subsistence (rice) farming in the relevant areas. But if it is true that rubber tapping and rice farming are competitive, which the figures suggest, this would be reflected in the net imports of rice. The available figures are given in Table 2.

Table 2 Net import of rice in long tons.

\begin{tabular}{c|rr|rr}
\hline Year & Palembang & W.A.Borneo \\
\hline & & & \\
1928 & 24.1 & $(100)$ & 39.0 & $(100)$ \\
1929 & 17.2 & $(71)$ & 34.4 & $(88)$ \\
1930 & 18.4 & $(76)$ & 32.9 & $(84)$ \\
1931 & 15.9 & $(66)$ & 25.2 & $(65)$ \\
1932 & 11.4 & $(47)$ & 24.4 & $(62)$ \\
1933 & 1.5 & $6)$ & 26.1 & $(67)$ \\
1934 & 7.0 & $(29)$ & 27.6 & $(71)$ \\
1935 & 5.0 & $(21)$ & 30.7 & $(78)$ \\
\hline
\end{tabular}

Imports show a marked decline in Palembang in particular. But imports into Wester Afdeling van Borneo also fell to $62 \%$ of the 1928 imports.

If subsistence farming competes with rubber production, it should be pos- 
sible to compute at what level of the purchasing power of rubber its production will become unattractive and greatly reduced. Two methods of computation are possible, viz. :

1. via the productivity level of subsistence farming,

2. via the subsistence economy based on a rice diet.

The productivity of subsistence farming in the regions under consideration was approximately $1500 \mathrm{~kg}$ rice equivalents per annum or $4.1 \mathrm{~kg}$ per day per family. The productivity of rubber tapping was $6 \mathrm{~kg}$ slab per day per family. When this productivity is reduced to a rice price level of $5 \frac{1 / 2}{12}$ ct per $\mathrm{kg}$, the comparable price of slab rubber will be $4.1 \times 5.5$ ct : $6=3.75$ ct per $\mathrm{kg}$, which means a price of about 12 ct per $\mathrm{kg}$ dry rubber at Batavia. The purchasing power of rubber $\frac{\text { (rubber price) }}{\text { (rice price) }}$ would then be $\frac{12}{5.5}=2.2 .{ }^{2}$ ). We have already seen that changes in the rubber production are closely correlated with changes in this price relation. In fact, the lowest rubber output coincides with the lowest figure of that quotient, viz. 2.2. in II - 1932.

In the subsistence economy based on a rice diet the welfare of the farmer can be expressed as the percentage of food expenditure to the total household expenditure, converted to rice equivalents.

At the lowest level food accounts for about $80 \%$ of total household expenditure (4) of which rice constitutes 2/3. It is thus possible to express the total household expenditure in rice equivalents, viz. $\frac{3}{2} \times$ rice consumption at this level, or rice consumption $+50 \%$. A family of six needs $2 \frac{1}{2} \mathrm{~kg}$ rice per day, so that the family's total needs at this level are $3 / 2 \times 2 / 2 \mathrm{~kg}$, or $3.75 \mathrm{~kg}$ rice equivalents per day. The same computations for higher levels of living in which food accounts for $70 \%$ or $60 \%$ show that the family's total needs are 4.2 and $5.0 \mathrm{~kg}$ rice equivalents. The computations gave the following results :

subsistence level

low

reasonable

\% food expenditure of total expenditure .... total expenditure per day in rice eq. ....... value at a price of $5.5 \mathrm{ct} / \mathrm{kg} \ldots \ldots \ldots \ldots$. price of rubber per $\mathrm{kg}$ slab to reach that income ......................... equivalent price at Batavia $\ldots \ldots \ldots \ldots \ldots$ purchasing power of rubber

\begin{tabular}{|c|c|c|}
\hline $80 \%$ & $70 \%$ & $60 \%$ \\
\hline $3.75 \mathrm{~kg}$ & $4.2 \mathrm{~kg}$ & $5.0 \mathrm{~kg}$ \\
\hline 20.6 ct & $23.1 \mathrm{ct}$ & $27.5 \mathrm{ct}$ \\
\hline 3.4 ct & 3.8 ct & 4.6 \\
\hline 11 ct & 12 ct & \\
\hline
\end{tabular}

On the strength of these computations rubber production will be greatly reduced when the purchasing power of that commodity falls below 3.0 ; at a level of 2.2 most producers will have turned to subsistence farming. After this point has been reached a moderate riste in purchasing power will cause a vigorous expansion in rubber production.

2) At the lowest point of rubber price and native rubber export the rice price was approximfately $f 5.50$ per $100 \mathrm{~kg}$. 
Table 3 Rubber exports $(1929=100)(1)$ and purchasing power of rubber in rice equivalents (2).

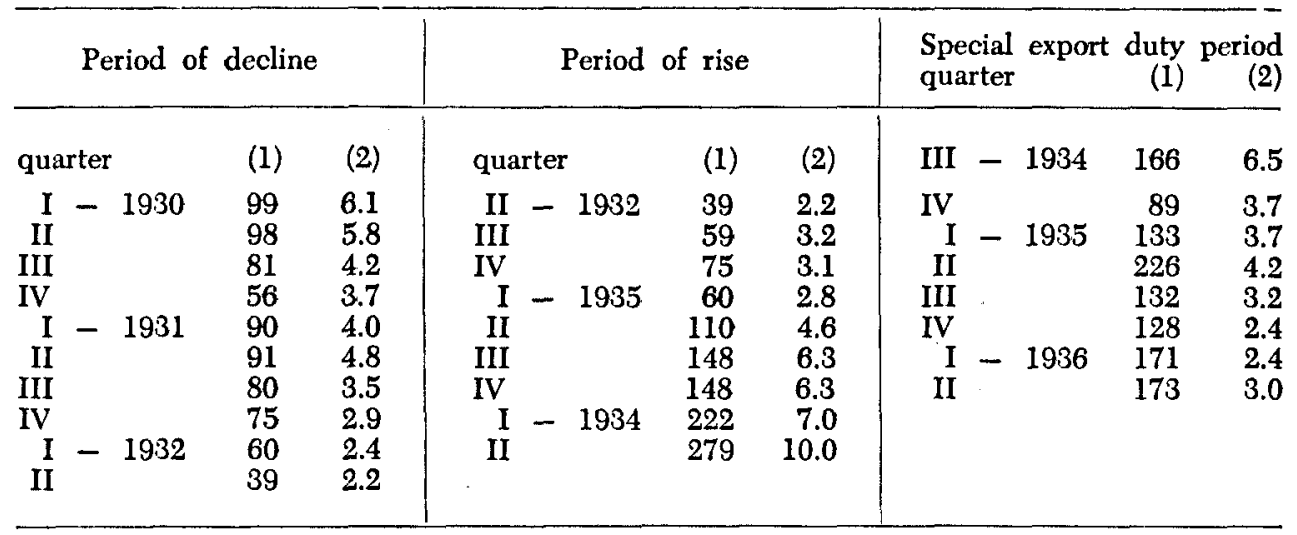

The statistical data are in striking agreement with expectations based on theoretical computations, so that the conclusion that subsistence farming competes with rubber tapping in the peasant economy of the regions in consideration seems fully justified. Consequently Professor BoEke was in error on this point and the conclusions drawn by BAUER and MARTIN are correct. If the peasant farmer has alternative opportunities no perverse supply curves are to be expected in the case of cash crop commodities. In this connection it is interesting to note that the statistical data on the production of the great rubber estates tend to exhibit a perverse supply curve. The index of the production of the estates in the Outer Provinces of Indonesia $(1929=100)$ for the years 1930-1934 were as high as $99 ; 108 ; 104 ; 111$; and 123 , whereas the figures for native rubber were $84 ; 84 ; 57 ; 116$ and 195 . The rubber estates had no alternatives.

\section{REFERENCES}

1 Martin, Anne: Economics and Agriculture. London, 1958; page 28.

2 Boeke, J. H. : The evolution of the Netherlands Indies economy. Haarlem, 1947, page 49.

3 Bauer, P. T. and B. S. YAMEY : The economics of underdeveloped countries. Cambridge Un. Press, 1957 ; page 197.

4 Huizenca, L. H. : The needs of the native farmer in the tropics and the raising of his level of living. Neth. J. Agr. Sc., Vol. 7, 1 Febr. 1959.

5 Reports on native rubber : Series of reports published in "Landbonw". Volumes 4-11, $1928-1936$ 